\title{
Inclusive Journalist Education in Croatia: Transformative Potential of Media
}

\author{
Zeljka Bagaric \\ Department of Communicology, Media and Journalism University North, Croatia
}

\begin{abstract}
.
The purpose of this article is to explore the idea of inclusive pedagogy as social justice that serves to develop the inclusive potentials of community media by strengthening the professional capacity of journalists and increasing the quality of media content. Recent official media discourse analysis conducted in Croatia has shown a number of problems in media coverage of vulnerable social groups. The existing media approach desensitizes the public to the specific problems such groups face, and in such way indirectly contributes to their social exclusion. Within this problem framework, a unique program of additional courses for journalists has been created aiming to build their intercultural competences for lifelong learning in promoting and applying desirable patterns of tolerance and social inclusion in their work. This service-learning courses will primarily sensitize journalists to the rights of vulnerable groups and further develop their professional competences for the appropriate media presentation of vulnerable groups, especially the ex-prisoners, in order to increase their visibility in society, raise public awareness of their rights and increase equal opportunities to work.
\end{abstract}

Keywords: academic service-learning; community media; social inclusion; social justice; vulnerable groups

\section{Introduction}

According to theoretical settings of social constructivism, human reality and social occurrences are cognitively created through social action (Berger\&Luckmann, 1966). The identity of each individual shapes the social practice of his social and cultural community in which, through constant interaction with others, the process of learning, knowledge constriction, significance and value attitudes take place as well as the formation of an individual's behaviour patterns (Wenger, 1991). By learning we acquire new knowledge and skills; this is a continuous process which changes the ability to participate in the environment, transforms the communication, identity and characteristics of an individual's engagement in the community (Terhart, 2003 according to Vrkic Dimic, 2011; Wenger, 1998). Large transformative potentials that are offered by dynamic nonformal and informal work and learning practice communities (Vrkic Dimic, 2011; Jenkins et al., 2011; Gorodetsky et al., 2003) should be encouraged and used in the context of participation and active citizenship. Modern universities are within the mentioned paradigms, and are definitely motivated by accreditation requests with the goal of achieving the standard of excellence in education, acquiring a new mission and models of knowledge and technology transfer. However, the production of knowledge, and acquiring of social and moral values for the development of graduates' professional competences for lifelong learning in applying desirable patterns of 
social justice in their work, is a task that has not been completely fulfilled by universities (Pavlik et. Al, 2020; Gregorutti, 2015; Furco \& Moely, 2012).

This paper discusses some of the settings of scientific disciplines dealing with complex issues of the transformative effects of education, communication and media discourse in the context of social justice, which may serve as a transdisciplinary theoretical framework for the establishment of a new supplementary education programme for journalists. In the mentioned theoretical and conceptual framework, the Croatian University North has successfully established, as one of the possible models, a set of courses for journalists in order to strengthen all professional capacities for quality media coverage and support to the social inclusion of vulnerable groups, in particular groups of returnees from imprisonment, whose establishment process will be described. Given that this paper deals with some features of instructional design within the framework of strengthening the professional competences of journalists in lifelong learning, epistemological issues related to reflective capacity building, mediation and translation as journalistic routines of journalistic students (Tischauser \& Benn, 2019) will not be considered.

\subsection{Social inclusion - process of creating the active citizen}

In Europe, there has been a shift in concepts at the research and socio-political level in recent decades (Sucur, 2004, Powell, 2003). The politics of Third Way and the vocabulary of "new labour discourse" in the UK in the 1990s handles topics such as: social inclusion, civil society, active government, investment in human and social capital, redistribution of opportunities and economic goods instead of income, positive social welfare, prevention, an active approach to employment and rights and responsibilities, and education and equality (Powell, 2003). Newly introduced topics always take the position of awareness of the entire community on the value of each individual and the model of inclusion, social inclusion and active engagement of an individual through which he contributes to his well-being. Inclusion in itself does not mean equalizing all people; on the contrary it implies respecting the diversity of each individual. Inclusion supports the needy individual in his efforts to feel as a part of community: it provides him with targeted support in his efforts to achieve his full potential. In this way, human and civil rights are protected and the status of an active citizen is guaranteed to each person because it enables him to make decisions on his own life and take full responsibility for it. The results of the conducted research indicate that participation in cultural and artistic activities and the ability to express feelings, perspectives and build their own identities within the community is effective in creating social/ public spaces for members of different marginalized groups and co-cultures (Warren, Jones, 2015; Orbe, Roberts, 2012; Thompson, 2012; Griffits, 1995). The term of indirect mediation (Shulz, 2004 ) is only briefly refered to in relation to the creation of public spaces or "forums", as an aspect of bridging spatial, cultural and social distance between different social actors (Shultz 2004: 91).

\subsection{Rehabilitation as social action}

In the past twenty years, new paradigms have been developed in the European criminological circle as a basis for a combined approach to researching the resilience of the population with the risk of recidivism. Although they are not yet sufficiently evolved, the positive results of the innovative rehabilitation programs and experimental studies on the subject of "education through culture and art", designed with the goal of personal growth and development, awareness and empowerment of creativity and potential talents of prisoners, pave the way for building more acceptable life styles (Bagaric et al. 2015; Hartley, Turvey, 2009; Maar et al. 2008; Hakemulder, 2000). According to the theoretical concept of 


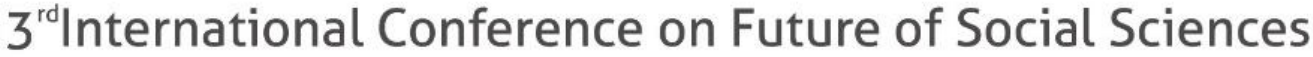

desistance (criminal behaviour) (Seaman and Lynch, 2016; Marsh and Maruna, 2016; Vaughan, 2007), the process of achieving sustainable socially acceptable lifestyles is shifting from the field of scientific research to the field of social movement. (Maruna, 2016). Although the perspective of cessation theory focuses on prisoner's relationships with researchers or other prisoners instead of treatment programs, it also includes a much broader network of influences on the individual that occur throughout life - such as family, employer, community, art and beyond, thereby enabling designing interventions for developing and building individual points of power. The plausible concept of empowering people behind bars, that is, those who leave bars behind them, in such ways returns from the world of penal and probation institutions to the community, where the cessation of criminal behaviour and socially acceptable life takes place (Maruna, 2016). This process of transformation in ideal conditions ends with full reintegration, which is facilitated by increasing the level of understanding and evaluation of other people's opinions, seeing the world from other perspectives and developing the empathy of all members in a community. In order to successfully construct a map of other people's intentions, as explained by the theory of mind (Bal and Veltkamp, 2013; Mar \& Outley, 2008; Mar, 2007), inclusive interventions should be targeted at all members of society.

Shifting the focus from the rehabilitation (Martinson) question of "what works" (Martinson, 1974) to the question of "how it works", in addition to having important implications for international judicial practice, at the same time constitutes a theoretical framework within which there are proposals, among other things, for research on potentials and the transformational role of the media as a support in the process of empowering and involving a vulnerable group of returnees from serving a prison sentence, as the focus of this paper. Although international experience (UK, Australia, Norway) on radio media content intended for the re-socialization tasks of prisoners and former prisoners has not yet been sufficiently evaluated, the results of successful projects (Bedford, 2014, Anderson, 2012) point to a transformative role of media content and activities associated with social inclusion in the context of positive social change.

\subsection{Media as an inclusive platform}

Community radio as a non-profit radio service is identified as a platform for participatory communication in the context of social change (Dagron, 2001), which is significant for the purposes of this paper. Community media, which enable for the "voices of the quietest ones" to be heard, are recognized by the Council of Europe (2009) as important promoters and facilitators of intercultural dialogue and strengthening of democratic processes. Community media can have an educational role in relation to wider audience and in such a way contribute to the inclusion of the disempowered members of society. European Parliament resolution on community media in Europe (2008) defines such media as non-profit organizations responsible towards the community they serve, with the primary aim of engaging in activities of public interest without making a profit. Community media serve, among other things, the interests of groups that would otherwise remain on the fringes of media attention, which is why the Resolution highlights their contribution to combating negative stereotypes towards socially marginalized groups that are often perpetuated by the mass media. In fact, various global research indicates that the mass media, and especially news media, influence the spread of various forms of discrimination. This is a consequence of news stories being repeatedly shared both by offline and online communication channels and in such way reaching people who would not be primarily exposed to such content (Kroon et al, 2016). In other words, news media frame stereotypical images and content for other media, especially 


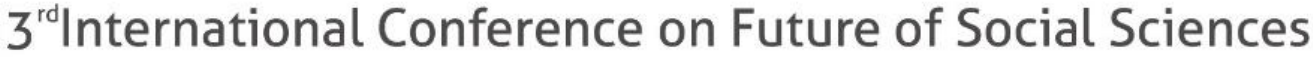

\section{5 - 7 March 2021}

for television (Kroon et al., 2018). Even in those situations where fair representation and the importance of diversity are proposed to be ensured through the construction of an inclusive news ecosystem, supported by the UNESCO model curricula (2007, according to Pavlik et al., 2020), groups underrepresented based on gender, ethnicity or sexual orientation remain to be mainly in the focus. Analyses conducted in recent years in Croatia (Bilic, 2020; Bilic et al., 2018) have shown that vulnerable social groups are poorly represented in the media and are often portrayed in a stereotypical manner. The problems in media coverage of vulnerable social groups are numerous. The existing media approach actually desensitizes the public to the specific problems faced by such groups and thus indirectly contributes to their social exclusion.

The most vulnerable group facing the highest risk of social exclusion is the group of women and men who return to the community after serving a prison sentence. Ex-inmates are minimally visible in society, faced with the stigmatization of committing crimes and discrimination in the labour market, where women ex-inmates are an even more vulnerable subgroup. It should be noted that this is not necessarily the result of shortcomings in the penal system. In Croatia, public opinion polls on ex-inmates are rare (Lotar, Kamenov, Lebedina Manzoni, 2010; Miksaj-Todorovic, Budanovac, 2000). However, the obtained results are in line with the relevant literature - they indicate to generally positive public attitudes towards ex-inmates and the rehabilitation process. Respondents state that the mainstream media generally do not appear as a stable and reliable source of information on the re-socialization of inmates and the efforts made in this direction by the justice system, treatment professionals and civil society organizations. The leading media agenda in this segment is "crime news", often framed within sensationalism. There are mostly scandalous stories of stumbled politicians published or events related to the most notorious members of the criminal milieu. The reasons for this can be found primarily in the negative bias of the media, that is in the market competition which, due to the behaviour of the media audience, dictates the dominant selection of negative content news (Soroka \& Mac Adams, 2015; Trussler \& Soroka, 2014; Arango-Kure et al, 2014). However, given the above data on the underrepresentation of vulnerable groups and stereotypical media presentation, we need to ask ourselves whether journalists themselves are subject to stereotypes without being aware of it. Are journalists sufficiently sensitized to the problems and obstacles that former inmates face upon return from civilian death? Are journalists educated enough on the subject of social inclusion?

\subsection{Teaching as social justice}

As mentioned above, the modern democratic society is characterized by multicultural communities. Education for active citizenship is becoming an educational ideal that should be strived for. Students should be educated so that in addition to their own understanding of identity they also understand identities of others, and in a way which enables them to achieve successful intercultural communication (Checkoway, 2001, according to Culum \& Ledic, 2010). In the last forty years, a large number of universities have been developing curricula that encourage the development of students' knowledge and skills through the experience of active participation in the local community (Mikelic Preradovic \& Mazeikiene, 2019, Culum $\&$ Ledic, 2010). There are two theoretical areas that deal with characteristics and organization in wider frames: social justice agenda - model academic service-learning and teacher agency within the inclusive pedagogy.

The theoretical basis of the experiential academic service-learning model are only briefly mentioned here: according to Culum \& Ledic (2010:81-83) those are primarily the philosophy of John Dewey pragmatism; critical pedagogy of Paolo Freire, and the 
experiential learning model of David Kolbe. It should be noted that academic servicelearning is significantly less represented in post-communist countries. In Croatia it can be found in less than a quarter of universities' strategic papers (from the total of 12) (Mikelic Preradovic \& Mazeikienè, 2019: 180). Due to a scientific dispute, two different names can be found in the literature - civic mission (Culum \& Ledic, 2010) i.e, academic service-learning (Mikelic Preradovic, 2009). This reflects the lack of consensus by theorists, so Kendall (1990, according to Culum \& Ledic, 2010) determined, by literature review, that there were 147 definitions and terms linked to service-learning. Furco (2001:67) defines academic service-learning as "a teaching strategy that enhances students' learning of academic content by engaging them in authentic activities in which they apply the content of the course to address identified needs in the local and broader community". Mikelic Preradovic (2009) defines it as an innovative approach to teaching and learning that brings students, academics, and community to jointly develop solutions for challenging issues. Without deeper discussion on the concept of "the third mission of the university" i.e. the ways and mechanisms of the university's integration into the community, the mentioned concept takes the point of view that modern transfer of knowledge and technology of higher scientific research, artistic and professional production does not only take place with the goal of developing economy and knowledge society, but also for the benefit of all members of the community. It should be noted that some theorists consider the social dimension (in addition to the economic or technological dimensions) of the university civic mission to be dominant (Checkoway, 2001; Ostrander, 2004; all according to Culum \& Ledic, 2011). In the context of designing innovative inclusive education models, four elements should be taken into consideration. The correlation of academic service-learning and community should be viewed through their interconnection: student education, curriculum transformation, research priorities based on current social problems of the community and the production of new knowledge, (Ostrander, 2004, according to Culum Ledic, 2011: 34), which is also seen important for this paper.

Modern inclusive pedagogy conceptualizes lecturers as agents of inclusion and social justice (Pantic \& Florian, 2015). Besides developing professional competences in order to achieve educational standards and quality of educational process, it is also important to develop and implement professional agency in teacher practice; it enables the transformation of their professional competences, identities and value systems into an inclusive professional capital leading to educational change (Molla \& Nolan, 2020). It should be emphasized that the inclusive pedagogy approach goes beyond the conceptual definition of inclusive education intended for (only) students with special educational needs (Pantic \& Florian, 2015). Relation dimension is important for agency since it is activated through interaction of the teachers' social circles. Agentic teachers can go beyond the curriculum to question the social justice implications of policies and school practices (Molla, Nolan, 2020). Although the author can, to a large extent, agree with the statement ,Journalism is not, and has never been, a general agent of democracy "(Tischauser \& Benn, 2019:4), a question rises in the scope of this paper: Can journalists become ,agents of social justice and embrace commitment to social justice as part of their professional approach "? (paraphrased according to Pantic \& Florian, 2015: 346).

\section{Approach}

Using interpretative approach, University North designed and conducted an exploratory research in the period 2018-2020. A qualitative methodology was used for collecting and processing data, applied to intentional samples and analysis units. Field methods were used 
for primary data (individual and focus interviews), and desk methods were used for secondary data (document and content analysis, reviews). Also, action research method (stakeholder analysis) and synthesis method were applied. Research purpose was to explore the idea of inclusive pedagogy as social justice that serves to develop the inclusive potentials of community media by strengthening the professional capacity of journalists and increasing the quality of media content.

\subsection{Objectives}

Within the presented theoretical and problem framework, the following general objectives were set:

1. Critically look at the plausibility of creating social/public spaces and discourses for members of different marginalized groups in order to increase their visibility and build their own identities within the community.

2. Map possible stakeholders of interinstitutional cooperation in the context of transdisciplinary communication inclusion.

3. Identify elements of a sustainable integrative curriculum of experiential communication learning in the community, focusing on members of individual vulnerable groups.

4. Analyse points of strength at University North as a holder of interinstitutional cooperation.

5. Design and implement inclusive education as social justice program.

Research questions are formulated: Is University North able, and in which way, to implement the principles of academic service-learning with a view of strengthening journalists' professional competences?

\subsection{Findings}

Different analytic procedures have been conducted within the three-year research period (2018-2020). Based on findings, designs and supplements with new research topic and courses with inclusive topics were brought parallel into the curriculum of University North (Table 1-2).

Table 1. Overview of research methods and outputs

\begin{tabular}{|l|l|l|}
\hline \multicolumn{1}{|c|}{ Objective } & Methods & \multicolumn{1}{c|}{ Outputs } \\
\hline $\begin{array}{l}\text { Critically look at the plausibility of } \\
\text { creating social/public spaces and } \\
\text { discourses for members of different } \\
\text { marginalized groups in order to increase } \\
\text { their visibility and build their own } \\
\text { identities }\end{array}$ & $\begin{array}{l}\text { Media content analysis; } \\
\text { Document analysis; } \\
\text { Reviews }\end{array}$ & $\begin{array}{l}\text { There are no formal journalist life-long } \\
\text { programs in Croatia which would support } \\
\text { social justice }\end{array}$ \\
\hline $\begin{array}{l}\text { Map possible stakeholders of inter- } \\
\text { institutional cooperation in the context of } \\
\text { trans-disciplinary communication inclusion }\end{array}$ & $\begin{array}{l}\text { Stakeholder analysis; } \\
\text { PEST analysis }\end{array}$ & $\begin{array}{l}\text { Main stakeholders identified: Faculty of } \\
\text { Education and Rehabilitation Sciences; } \\
\text { Ministry of Justice and Culture; Prison/ } \\
\text { Probation system; NGOs }\end{array}$ \\
\hline $\begin{array}{l}\text { Identify elements of a sustainable } \\
\text { integrative curriculum of experiential } \\
\text { communication learning in the community } \\
\text { at University North }\end{array}$ & $\begin{array}{l}\text { Document analysis; } \\
\text { Interviews; Focus groups }\end{array}$ & $\begin{array}{l}\text { Elements: Development of life-long learning } \\
\text { competence; Knowledge multiplying; } \\
\text { Increasing research competitiveness; } \\
\text { Contribution to employment policy }\end{array}$ \\
\hline $\begin{array}{l}\text { Analyse points of strength at University } \\
\text { North as a holder of interinstitutional } \\
\text { cooperation }\end{array}$ & SWOT analysis & $\begin{array}{l}\text { Media community project ,eRadio for second } \\
\text { chance “ }\end{array}$ \\
\hline $\begin{array}{l}\text { Design and implement courses of } \\
\text { education as social justice }\end{array}$ & $\begin{array}{l}\text { (Revised) Boolean } \\
\text { taxonomy; Instructional } \\
\text { Designing }\end{array}$ & $\begin{array}{l}\text { Revised topics of research strategies } \\
\text { Revised syllabi }\end{array}$ \\
\hline
\end{tabular}


Source: (by author)

Table 2. Summary of achieved research outcomes by timeline

\begin{tabular}{|c|l|}
\hline Year & \multicolumn{1}{c|}{ Outcomes } \\
\hline 2018 & $\begin{array}{l}\text { Supplemented Scientific-Research Strategy of University North (2014-2019) with topic } \\
\text { Transformational potential of radio in inmate re-socialization) }\end{array}$ \\
\hline 2019 & $\begin{array}{l}\text { - Supplemented Scientific-Research Strategy of University North (2020-2025) with topics: } \\
\text { - Development and strengthening of intercultural competences in communication with vulnerable } \\
\text { groups; Media and community: transformational potential of radio } \\
\text { - Supplemented graduate level syllabus: Course "Communication with vulnerable groups" } \\
\text { - Supplemented undergraduate level syllabus: Course "Communication and social inclusion" }\end{array}$ \\
\hline 2020 & $\begin{array}{l}\text { - Scientific-research strategy of PhD studies at University North (2019-2023) included } \\
\text { the field: Media transformation and transformative effects of communication: Topics: Media in } \\
\text { community; Media and social inclusion; Empowering vulnerable groups through communication tools; } \\
\text { Communication and rehabilitation. } \\
\text { - Accepted inclusive community media project lead by internet student radio journalists "eRadio for } \\
\text { second chance", co-funded by European Social Fund (ESF) }\end{array}$ \\
\hline 2020 & \begin{tabular}{l} 
Created and conducted service-learning training for internet student radio journalist \\
\hline
\end{tabular} \\
\hline
\end{tabular}

Source: (by author)

Within the European Social Fund, and innovative project of University North "eRadio for second chance" was accepted during 2020. The project was both created and led by the author of this paper. The project aims to develop the inclusive potential of community media for social inclusion by strengthening the capacity of journalists and increasing the quality of media content at student internet radio „Pressedan“. It aims to increase the visibility of vulnerable groups of both male and female returnees from prison into society and contribute to increasing equal opportunities in the labour market and their reintegration into the community. In order to provide experiential learning to radio journalists and strengthen all their capacities, a unique service-learning training was designed and implemented (Table 3). In the framework of inter-institutional cooperation, in addition to lecturers from University North, renowned experts in penal system, probation, rehabilitation and resocialization, were engaged as lecturers. Additionally, representatives from creative NGOs with experience in implementation of successful projects were also engaged in order to transfer their good practice examples.

Table 3. Service-learning training for internet radio journalists (instructional design)

\begin{tabular}{|l|l|}
\hline Constraints & $\begin{array}{l}\text { Service-learning training for internet radio journalists } \\
\text { of Ministry of culture and media; Instructors: 10; Facilities: online due to COVID-19 crisis; } \\
\text { Certification: Certificate of participation; SQF level:6 }\end{array}$ \\
\hline $\begin{array}{l}\text { Training } \\
\text { outline }\end{array}$ & $\begin{array}{l}\text { 4 Modules: 1. Paradigm of rehabilitation, re socialization and desistance (from crime) 2. Public } \\
\text { educational campaigns; 3. Journalistic ethics and media ecology; 4.Innovative methods and } \\
\text { technologies in radio journalism }\end{array}$ \\
\hline $\begin{array}{l}\text { Learning } \\
\text { outcomes }\end{array}$ & $\begin{array}{l}\text { - } \begin{array}{l}\text { critically reflect and self-evaluate their own beliefs and values, } \\
\text { integrate core values of social justice principles, }\end{array} \\
\text { - identify mass media misrepresentation of vulnerable groups and assess how it affects their } \\
\text { inclusion and integration, }\end{array}$ \\
\hline $\begin{array}{l}\text { - enhance professional competences required by journalist to appropriate present vulnerable } \\
\text { groups in media, especially the ex-prisoners, } \\
\text { strengthen the intercultural competences for lifelong learning in promoting and applying } \\
\text { desirable patterns of tolerance and social inclusion in their work. }\end{array}$ \\
\hline
\end{tabular}

Source: (by author) 


\section{Conclusion}

The main motivation behind writing this paper is the search for an answer to a question whether the existing higher education of journalists in Croatia enables good quality and successful application of acquired knowledge and skills to different audiences within the community, in the context of creating a media agenda that supports the identity of marginalized groups. All of the above-mentioned demonstrates that building and strengthening the social, intercultural and other professional competences of journalists for media reporting serves as an inclusive platform that can be realistically and successfully established in form of academic service-learning training and courses. At the policy level, social justice habitus is recognized as professional capital that leads to educational change. However, in order to achieve the transformative media effects within the new educational realities, it is necessary to further encourage the transformation of professional competences and value systems of journalism lecturers so that both lecturers and students could accept social justice as a permanent feature of their profession.

\section{References}

Anderson, H. (2012). Facilitating Active Citizenship: Participating in Prisoners' Radio. Critical Studies in Media Communication, vol. 30(4), pp. 292-306. DOI: 10.1080/15295036.2012.688212.

Arango-Kure, M., Garz, M., Rott, A. (2014). Bad News Sells: The Demand for News Magazines and the Tone of Their Covers, Journal of Media Economics, vol. 27(4). pp. 199214, DOI: 10.1080/08997764.2014.963230.

Bagarić, Z, Miksaj-Todorovic, L., Butorac, K. (2015). Guided Reading Programme for Prisoners: An Outcome- Oriented Approach, Journal of special education and rehabilitation, 16, 1-2; 85-104 doi:10.1515/JSER-2015-0006.

Bal, P. M., Veltkamp, M. (2013). How does fiction reading influence empathy? An experimental investigation on the role of emotional transportation, PLOS ONE 8(1): e55341. doi:10.1371/journal.pone.0055341.

Bedford, C. (2014). Can alternative media redefine public service broadcasting? Prison radio and the BBC. Annual International Conference on Journalism and Mass Communication, Singapore, 22-23 September, pp. 105.

Berger, P. L., Luckmann, T. (1966). The Social Construction of Reality: A Treatise in the Sociology of Knowledge, New York: Doubleday.

Bilic, P. (2020). Monitoring Media Pluralism in the Digital Era: Application of the Media, Pluralism Monitor in the European Union, Albania and Turkey in the years 2018-2019. https://cadmus.eui.eu/bitstream/handle/1814/67796/croatia_results_mpm_2020_cmpf.pdf?seq uence $=1 \&$ is Allowed $=\mathrm{y}$.

Bilic, P., Petricusic, A., Eterovic, R. (2018). Media Pluralism Monitor 2017, Monitoring risks for media pluralism in EU and beyond. Country Report: Croatia, Available at: http://cmpf.eui.eu/wp-content/uploads/2018/11/Croatia_MPM2017_country-report.pdf .

Bringle, R., Hatcher, J. (1995). A Service Learning Curriculum for Faculty, Michigan Journal of Community Service Learning, vol. 1, pp. 112-122. 
Checkoway, B. (2001). Renewing the civic mission of the American research university, Journal of Higher Education, vol. 72(2), pp. 125-147. doi:10.2307/ 2649319.

Culum, B., Ledic. J. (2011). Sveucilisni nastavnici i civilna misija sveucilista, Rijeka: Filozofski fakultet u Rijeci.

Culum, B., Ledic, J. (2010). Učenje zalaganjem u zajednici - integracija visokoškolske nastave i zajednice u procesu obrazovanja društveno odgovornih i aktivnih građana. [ServiceLearning - The Integration of Higher Education and the Community in the Process of the Education of Socially Responsible and Active Citizens], Revija za socijalnu politiku, vol. 17,1, pp. 71-88. https://hrcak.srce.hr/index.php?show=clanak\&id_clanak_jezik=75223.

Dagron A. (2001). Making waves: stories of participatory communication for social change, New York: The Rockefeller Foundation.

Coucil of Europe (2009). Declaration of the Committee of Ministers on the role of community media in promoting social cohesion and intercultural dialogue.

Dewey, J. (1938). Education and Experience, NY: Macmillan.

Eckert, P., Wenger, E. (1994). From school to Work: An Apprenticeship in Institutional Identity. Learning and Identity Series, Palo Alto, CA: Institute for Research on Learning, http://www.ewenger.com/pub/Institutional_identity_wrd.doc.

European Parliament resolution of 25092008 on Community Media in Europe (2008/2011(INI))http://www.europarl.europa.eu/sides/getDoc.do?pubRef=//EP//TEXT+TA+P6-TA-2008-0456+0+DOC+XML+V0//EN.

Furco, A., Moely, B. (2012). Using Learning Communities to Build Faculty Support for Pedagogical Innovation: A Multi-Campus Study, Journal of Higher Education, vol. 83(1), pp. 128-153.

Furco, A. (2001). Advancing service-learning at research universities, New Directions for Higher Education, 114, pp. 67-78.

Gorodetsky, M., Keiny, S., Barak, J., Weiss, T. (2003): Contextual pedagogy: Teachers' journey beyond interdisciplinarity, Teachers and Teaching: theory and practice. Vol. 9,1., pp. 21-33.

Gregorutti, G. (2015). Enriching Higher Education Training through Values and Social Engagement, BCES Conference Books: Quality, Social Justice and Accountability in Education Worldwide, 13, 1, pp. 423-428. https://files.eric.ed.gov/fulltext/ED568595.pdf.

Griffiths, R. (1995) Cultural strategies and new modes of urban intervention. Cities, vol. 12(4) pp. 253-265.

Hakemulder, J.F. (2000). The Moral Laboratory: Experiments Examining the Effects of Reading Literature on Social Perception and Moral Self-concept, Amsterdam: John Benjamins.

Hartley, J., Turvey, S. (2009). Reading together: the role of the reding group inside prison, Prison Service Journal, No. 183, pp. 27-32.

Howard, J.P.F. (1998). Academic Service Learning: A Counternormative Pedagogy.// In R. A. Rhoads and J.P.F. Howard (eds.), Academic Service Learning: A Pedagogy of Action and Reflection, New Directions for Teaching and Learning, no. 73. San Francisco: JosseyBass. 
ICDE \& UNESCO (2015). Online, open, and flexible higher education for the future we want: discussion paper. http://icde.typepad.com/files/discussion-paper-----paris-forum--final-version.pdf .

Jacoby, B. (1996). Service-Learning in Higher Education: Concepts and Practices, San Francisco: Jossey-Bass.

Jenkins, H., Clinton, K., Purushotma, R., Robison, A. J., Weigel, M. (2007). Confronting the Challenges of Participatory Culture: Media Education for the 21st Century, Chicago: The MacArthur Foundation. http://www.digitallearning.macfound.org/atf/cf/\%7B7E45C7E0A3E0-4B89-AC9C-3807E1B0ae4e\%7D/JENKINS_WHITE_PAPER.PDF.

Josic, H., Mikelic Preradovic, N. (2019). Entrepreneurship and Service Learning of Students of Information Sciences and Informatics. INFuture2019: Knowledge in the Digital Age. Zagreb, Croatia, pp. 166-173. Doi: 10.17234/INFUTURE.2019.20.

Kendall, J.C. (1990). Combining Service and Learning: An Introduction.// Jane C. Kendall and Associates (eds.), Combining Service and Learning: A Resource Book for Community and Public Service (National Society for Internships and Experiential Education, Raleigh, N.C.), pp. 1-33.

Kroon, A.C., Trilling, D., Van Selm, M., Vliegenthart, R. Biased media? (2018). How news content influences discrimination claims, European Journal of Ageing. https://doi.org.10.1007/s10433-018-0465-4.

Kroon, A.C., Van Selm, M., Ter Hoeven C.L., Vliegenthart, R. (2016). Reliable and unproductive? Stereotypes o folder employees in corporate and news media, Ageing Soc. http://doi.org/10.1017/S0144686X16000982.

Lazarsfeld, P. F., Merton, R. K. (1948). Mass Communication, Popular Taste and Organized Social Action.// In L. Bryson (Ed.), The Communication of Ideas: A Series of Addresses, pp. 95-118. New York, NY: Harper \& Row.

Lotar, M., Kamenov, Z., Lebedina Manzoni, M. (2010). Gender differences in stigmatization of convicted offenders, Kriminologija \& Socijalna Integracija vol. 18(2), pp. 15-27. https://hrcak.srce.hr/index.php?show=clanak\&id_clanak_jezik=93629.

Mar, R.A., Djikic, M., Oatley, K. (2008). Effects of reading on knowledge, social abilities, and selfhood. //In S. Zyngier, M. Bortolussi, A. Chesnokova, J. Auracher (Eds.). Directions in empirical studies in literature: In honor of Willie van Peer, pp. 127-137. Amsterdam: Benjamins.

Mar, R.A. (2007). Simulation-based Theories of Narrative Comprehension: Evidence and implications, $\mathrm{PhD}$ dissertation, University of Toronto.

Marsh, B., Maruna, S. (2016). Desistance and restorative justice: learning from success stories of Northern Ireland's Youth Justice Agency, Restorative Justice, vol. 4(3), pp. 369387. DOI: $10.1080 / 20504721.2016 .1243855$.

Maruna, S. (2016). Desistance and restorative justice: it's now or never, Restorative Justice vol. 4(3), pp. 289-301. DOI: 10.1080/20504721.2016.1243853.

Martinson, R. (1974). What Works? Questions and Answers About Prison Reform, Public Interest, vol. 35, pp. 22-53.

Mikelic Preradovic, N. (2009). Ucenjem do drustva znanja: teorija i praksa drustveno korisnog ucenja, Zagreb: Zavod za informacijske studije. 
Mikelic Preradovic, N. Mazeikienè, N. (2019). Service-learning in post-communist countries. Embedding Service-learning in European Higher Education,// Aramburuzabala, P; McIlrath, L; Opazo, H. (eds.), Routledge, London, 180-195. ISBN: 978-1-138-08973-0.

Miksaj-Todorovic, Lj., Budanovac, A. (2000). Public opinion toward offenders and rehabilitation in Croatia: the impact of gender, age, education and level of urbanization, Kriminologija \& socijalna integracija: casopis za kriminologiju, penologiju i poremecaje $u$ ponasanju, vol. 8,1-2, pp. 35-42. URL: https://hrcak.srce.hr/98951.

Molla, T., Nolan, A. (2020) Teacher agency and professional practice, Teachers and Teaching, vol. 26, 1, pp. 67-87, DOI: 10.1080/13540602.2020.1740196.

Orbe P., Roberts L. T. (2012). Co-Cultural Theorizing: Foundations, Applications \& Extensions, The Howard Journal of Communications, 23 (4), 293-311.

Ostrander, S.A. (2004). Democracy, Civic Participation, and the University: A Comparative Study of Civic Engagement on Five Campuse, Nonprofit ad Voluntary Sector Quarterly, vol. 33, 1, pp. 74-93 DOI:10.1177/0899764003260588.

Pantic, N., Florian, L. (2015). Developing teachers as agents of inclusion and social justice. Education Inquiry, vol. 6, 3, 27311, DOI: 10.3402/edui.v6.27311.

Pavlik, J. V., Alsaad, A.A., Laufer, P. (2020) Speaking Truth to Power: Core Principles for Advancing International Journalism Education. Journalism \& Mass Communication Educator 2020, vol. 75(4) pp. 392-406. https://doi.org/10.1177/1077695820946241

Powell, M. (2003). The Third Way. //Alcock, P., Erskine, A., May, M. (ed) The Student's Companion to Social Policy: 2nd Edition. Oxford: Blackwell Publishers.

Seaman, V., Lynch, O. (2016). Learning the basics of how to live: ex-prisoners' accounts of doing desistance, Irish Probation Journal, vol. 13, pp. 65-83 http://www.probation.ie/

Schulz, W. (2004). Reconstructing Mediatization as an Analytical Concept, European Journal of Communication, vol. 19, pp. 87-101.

Soroka, S., McAdams, S. (2015). News, Politics, and Negativity, Political Communication, vol. 32(1), pp. 1-22.

Sucur, Z. (2004). Socijalna iskljucenost: pojam, pristupi i operacionalizacija, Zagreb: Pravni fakultet.

Terhart, E. (2003): Constructivism and teaching: a new paradigm in general didactics? Journal of Curriculum Studies, vol. 35.,1, pp. 25-44.

Tischauser, J., Benn, J. (2019) Whose Post-Truth Era? Confronting the Epistemological Challenges of Teaching Journalism, Journalism \& Mass Communication Educator. Special Issue: Teaching in Post-Truth: Challenges, Lessons, and Innovations in Journalism Education. 1-13. https://doi.org/10.1177/1077695819837406.

Thompson, N. (2012). Living as Form-Socially Engaged Art from 1991-2011, The MIT Press. Cambridge, Massachusetts.

Trussler, M., Soroka, S. (2014). Consumer Demand for Cynical and Negative News Frames, The International Journal of Press/ Politics, vol.19(3) pp. 360-379.

UN (2015). A/RES/70/1. Transforming our world: the 2030 Agenda for Sustainable Development, https://sdgs.un.org/publications/transforming-our-world-2030-agenda-17981. 


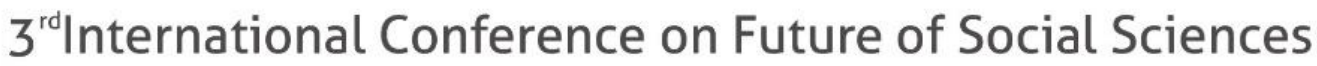

Vandzinskaite, D., Mazeikiene, N., Ruskus, J. (2010). Educational Impact Social Sciences /of Service-Learning: Evaluation of Citizenship and Professional Skills Development, vol. 4 (70), pp. 3-17.

Vaughan, B. (2007). The Internal Narrative of Desistance, British Journal of Criminology vol. 47(3), pp. 390-404. DOI: 10.1093/bjc/azl083.

Vrkic Dimic, J. (2011). Ucenje kroz prizmu socijalnog konstruktivizma, Acta Iadertina, vol. 8, pp. 77-90.

Warren, S. Jones, P. (2015). Local governance, disadvantaged communities and cultural intermediation in the creative urban economy, Environment and Planning C: Government and Policy, 33, pp. 1738-1752.

Wenger, E. (1998). Communities of practice: Learning as a Social System, Systems Thinker.vol. 9 (5), pp. 4-13., http://ewenger.com/pub/pub_systems_thinker_wrd.doc.

Wenger, E. (1991). Communities of practice: where learning happens, Benchmark Magazine. vol 4. pp. 32-41, http://www.ewenger.com/pub/pub_benchmark_wrd.doc. 